Article

\title{
The Categorized and Invisible: The Effects of the 'Border' on Women Migrant Transit Flows in Mexico
}

\author{
Carla Angulo-Pasel \\ Balsillie School of International Affairs, Wilfrid Laurier University, Waterloo, ON N2L 6C2, Canada; \\ cangulo-pasel@balsillieschool.ca
}

Received: 26 February 2019; Accepted: 25 April 2019; Published: 8 May 2019

\begin{abstract}
In an increasingly globalized world, border control is continuously changing. Nation-states grapple with 'migration management' and maintain secure borders against 'illegal' flows. In Mexico, borders are elusive; internal and external security is blurred, and policies create legal categories of people whether it is a 'trusted' tourist or an 'unauthorized' migrant. For the 'unauthorized' Central American woman migrant trying to achieve safe passage to the United States (U.S.), the 'border' is no longer only a physical line to be crossed but a category placed on an individual body, which exists throughout her migration journey producing vulnerability as soon as the Mexico-Guatemala boundary is crossed. Based on policy analysis and fieldwork, this article argues that rather than protecting 'unauthorized' migrants, which the Mexican government narrative claims to do, border policies imposed by the state legally categorize female bodies in clandestine terms and construct violent relationships. This embodied illegality creates forced invisibility, further marginalizing women with respect to finding work, and experiences of sexual violence and abuses by migration actors. The analysis focuses on three areas: the changing definition of 'borders'; the effects of categorization and multiple vulnerabilities on Central American women; and the dangers caused by forced invisibility.
\end{abstract}

Keywords: borders; women; Mexico; violence; security; Central America

\section{Introduction}

Since the 1960s, border controls in the United States have undergone a transformation and become more restrictive towards 'unauthorized' migrants (Nevins 2001). Whereas in the past, border controls were typically focused on external, geographical and territorial demarcations (Walters 2006), border enforcement is increasingly practiced both at territorial borders and internally within nation-states (Parker and Vaughan-Williams 2012). The nation-state, through border security policy, has also created categories of migrants. Despite employing a rhetoric of protection, such categories place certain people in more precarious situations during their migration. This article takes, as its starting point, the categories nation-states use to refer to irregular migrants (including 'unauthorized', 'illegal', 'irregular', 'alien', and 'foreigner') and examines how these categories make migrants more vulnerable when crossing international borders. These state-produced categories place migrants in more dangerous and risky situations and affect their mobility and human rights. The danger facing migrants may be more pronounced during the journey from the country of origin to the country of destination. This is because the journey, or being in-transit, represents a state of limbo for migrants in which they can no longer rely on accessing the legal rights associated with their citizenship. Thus, given their 'unauthorized' status, they may be more prone to human rights abuses and insecurity while in transit. 
Through its border enforcement controls, the nation-state contributes to the securitization of migration $^{1}$, and produces 'unauthorized' migrants by virtue of assigning that category to an individual person. When a person is classified as being 'illegal' or 'unauthorized', this label follows him or her throughout the migration journey. Therefore, when a body is classified in clandestine terms, a migrant embodies this illegality and must travel with it. This is evident in Mexico, especially in the case of women migrants generally, and women migrant workers (WMWs) specifically. Over the past several years, the number of Central American migrants entering Mexico in the hopes of reaching the U.S. has steadily increased. For example, the year 2015 saw a total of 198, 141 'irregular' migrants enter Mexico (Secretaría de Gobernación SEGOB). Between 90 and 94 percent of this population originates from Central America-principally from Guatemala, Honduras, and El Salvador-and they mainly enter Mexico through the border zone in Chiapas (Diaz Prieto and Kuhner 2014, p. 16). In 2015, the Instituto Nacional de Migración (INM) detained a total of 179,618 migrants from Central America of which close to 50 percent were from Guatemala, another 33 percent were from Honduras, and 20 percent were from El Salvador (Secretaría de Gobernación SEGOB). It is important to note that these official statistics do not demonstrate the number of migrants who avoid detention and, thus, it is difficult to statistically measure the whole 'unauthorized' or 'irregular' population of migrants. It is equally difficult to estimate the number of women migrants that transit through Mexico in order to reach the U.S. Nevertheless, reports place this estimate between 20 and 25 percent of the total 'unauthorized' transit population (Diaz Prieto and Kuhner 2014). This rise in migrants from Central America has implications not only for the U.S., but also for the Mexican government, as it attempts to address the needs of this population. From a security perspective, border control logics implemented by the U.S. are extending into Mexico, where it appears the U.S. border with Mexico is stretching outward, through Mexico, to the Mexican southern border with Guatemala. The humanitarian consequences of this border control on 'unauthorized' women migrants from Central America transiting through Mexico have been alarming to human rights activists and non-governmental organizations (NGOs) alike (Washington Office on Latin America WOLA; Isacson et al. 2015; IACHR 2015).

This article examines how state border controls further marginalize Central American women migrants transiting through Mexico, making them more insecure while travelling and searching for employment en route. I argue that border controls, implemented by the nation-state, construct categories of illegality and force women to become invisible, both of which enhance women migrants' danger and vulnerability while in transit (Anderson 2012; De Genova 2004; Mountz 2015). Women from the so-called Northern Triangle of Central America (NTCA) already embody multiple vulnerabilities connected to the institutionalized social relationships that organize power hierarchies (Pessar and Mahler 2003). For instance, they may originate from a poor economic class, or may be victims of gender-based violence (GBV). All of these social processes form a social structure and position women within specific interconnected power hierarchies. Using this conceptual framework of social location based on institutionalized structures that are created through social differences, I highlight how border practices are part of this power structure. Imposing an unfavourable border category in this context adds one more oppressive structure that women must navigate during their journey.

\section{Methodology and Sections}

Building on research carried out in 2014, my analysis relied on Mexico's Programa Frontera Sur (PFS) and the regional visitor visa [Tarjeta de Visitante Regional] to critically assess the government discourse vis-à-vis 'irregular' migrants and governance practices employed in the name of human rights

1 In this article, I refer to the securitization of migration to indicate how migration has been socially constructed as a security issue, framing it as a threat to public society, cultural homogeneity, and/or labour market stability (Huysmans 2000). Socially and politically, therefore, there is a sustained public perception that 'irregular' migrants need to be contained or excluded by using restrictive border enforcement practices. The creation and maintenance of this securitization involves multiple actors, norms, and practices, similar to what has been referred to as a 'security assemblage' (Abrahamsen and Williams 2009). 
and protection. My analysis further relied on data from participant observation and 27 semi-structured interviews, gathered during fieldwork that took place from September to December in Mexico. I employed a feminist perspective, which in turn informs my epistemological understanding and commitments. As a researcher who is committed to understanding the lives of people who are typically marginalized from hegemonic security narratives, I employed research methods that provided a view of the world that prioritizes the voices of migrant women. I adopted a view of 'knowledge' which enabled the questioning of dominant power structures, how they 'fit into the rest of social life' (Sprague 2016), and thus, exposed the social inequalities among women whose experiences and subjectivities are constructed in subordination. My research took place in the states of Oaxaca and Veracruz, which I selected on the basis that they are major points along the transit route for migrants who are travelling to the U.S.-Mexico border. These transit routes are also well-known to migrants due to the trajectory of the cargo freight train, infamously known as 'La Bestia' [The Beast]. Overall, these qualitative methods allowed me to spend time in places where women migrants travel and often live for long periods of time and to learn about and describe aspects of their lives with accuracy guided by the voices of migrant women and their advocates and communities. In particular, this approach strengthened my representation of their practices of (im)mobility as well as their survival, their fears, and their emotional traumas.

The first section of the article provides a background of the concept of borders and the shift from physical borders to what may be referred to as 'bordering' (Rumford 2011). It delves into some border logics implemented by the U.S. and shows how this governance is being extended into Mexico, especially with the implementation of the PFS policy, and reveals how border security logics sustain the perception of migrants as 'threats' using security narratives, which in turn affects migrant women's insecurity by forcing them to remain hidden. The second section examines how subordinate border enforcement categories imposed by the nation-state intersect with other categories that are socially constructed through lived experiences of oppression, and encourage the continued marginalization of migrant women, not only as they attempt to negotiate safe passage while they travel through Mexico, but equally as they attempt to find work. Section Three delves into the problem of invisibility where, given the 'unauthorized' nature of their status, migrant women find themselves living in a constant state of fear and unable to seek various forms of protection (health, employment, assistance from police, etc.). Feeling the need to remain invisible and hidden due to the threat of detainment and/or deportation, they are unable to access human or labour rights, which places them in more vulnerable situations. By forcing migrants to live clandestinely, the nation-state, in effect, contributes to the creation of a shadow or illicit labour market within an informal economy, as these women are often unable to acquire 'legitimate' or 'regular' forms of work.

\section{What Is the 'Border'?}

International security discourse plays an important role in securitizing global migration by framing it as a 'threat', and the concept of 'borders' is significant in this narrative. Scholarly work conceptualizing the 'border' has flourished to address the border well beyond simply viewing it as a physical, territorial line where one nation-state meets another (Balibar 2002; Huysmans 2000; Huysmans 2006; Walters 2006; Rumford 2006; Rumford 2011; Johnson et al. 2011; Parker and Vaughan-Williams 2009; Parker and Vaughan-Williams 2012). Johnson et al. (2011), for example, discuss how the 'border' has changed in terms of place, perspective, and performance. Historically, with regards to 'place', the border was understood in strictly physical, geographical terms of fixed territorial lines demarcating one sovereign state from another. This fixed line at the geographical edge of a nation-state, defining a territory with official ports of entry (POEs), (whether on land, water, or in airports), was to be militarily defended from enemy armies (Walters 2006). In terms of 'perspective', therefore, the principal actor involved with questions of 'who borders' or who sustains the border, was the nation-state. This state-centric focus, typical of dominant International Relations (IR) theory, positioned border policy within a national security narrative. 
Beginning in the 1990s, with what Kaldor (2007) refers to as 'new wars', the border's 'place' as a strictly territorial line was challenged by the new global security 'threat' of 'unauthorized' migration. As Huysmans (2000) notes in the European context, asylum was racialized and negatively portrayed as most of the asylum-seekers were migrating from the 'developing' world. In the IR literature, this migration 'threat' was framed as one of 'high international politics' that required state-centric responses due to the internal instability that this international security crisis would generate (Weiner 1993). Indeed, migration was framed as a danger to domestic society, whether to cultural homogeneity, or to the social welfare system. Consequently, nation-state actors viewed the regulation of this migration, through border controls, as necessary in order to protect internal security (Huysmans 2000). The state had to be pre-emptive and ensure that this migratory 'threat' did not reach official territorial lines and thus the border started to shift-expanding externally and internally—promoting a 'delocalization' of the border (Walters 2006, p. 193). In the North American context, Lahav and Guiraudon (2000, p. 55) discuss this delocalization as the state's 'remote control' (see Zolberg 1999), enlisting the help of private actors, like ranchers in Arizona for instance, to 'forestall migration at the source'. Furthermore, if these 'unauthorized' migrants were successful in crossing the official border, government authorities needed to apprehend and, subsequently, deport 'unauthorized' migrants. Essentially, Bigo (2002, p. 76) argues that, similar to the notion of a Möbius ribbon, where one surface appears to have two distinct sides, the migration 'threat' blurs the lines between internal and external border security, where different security agencies all participate and cooperate in their struggle against migration.

As a result of this changing perception of migration and border governance, there is a theoretical shift among critical scholars from 'borders' to the idea of 'bordering'. This is significant because borders are no longer conceptualized as fixed lines but rather processes and practices occupying both internal and external spaces (Rumford 2011; Bigo 2002; Salter 2004; Amoore 2006). Focusing on practices is critical as it helps to identify how borders are constituted and sustained, by whom, and also reveals the consequences of these practices on people's everyday lives (Parker and Vaughan-Williams 2012, p. 729). In addition, the combination of practices and its effects on people illustrates the spatial and temporal dimensions of borders. As Balibar (2002, p. 71) noted, borders are 'profoundly changing ... to preserve the functions of the sovereignty of the state' by being 'dispersed a little everywhere'. Spatially, therefore, borders may follow an 'unauthorized' migrant into towns and cities. Borders appear essentially wherever an 'unauthorized' or 'undocumented' migrant is asked to identify himself or herself. Temporally, the border practices that categorize the migrant as 'illegal' can last a lifetime, as evidenced by the 'unauthorized' youth who were brought to the U.S. as children and are protesting for regular status.

Border governance also increasingly reflects practices of treating borders not just as physical boundaries but also as virtual and non-physical forms of borders. For example, governments along with private actors, such as airline companies, now employ technologies of pre-entry, entry, and exit (Salter 2008). Amoore (2011) refers to this border expansion as 'spatial stretching' whereby biometric technologies and risk profiling operate well beyond nation-state borders. Entry, therefore, extends all the way to pre-departure at the country of origin, and bordering practices are equally exercised internally. In the U.S. context, for example, borders are constantly moving internally due to the movement of border enforcement officials to internal checkpoints which can be within $100 \mathrm{~m}$ of a POE (Mountz 2011), to local cities in the U.S. with 287 (g) agreements ${ }^{2}$ or programs like Secure Communities, which are local-federal immigration partnerships allowing local police officials to conduct immigration enforcement (Coleman 2012). Traveler status management is yet another example where those travelers who have entered a state may be tracked while inside to ensure they do not overstay, similar to the functions of the Office of Biometric Identity Management (OBIM), which replaced the US-VISIT

2 Part of the Illegal Immigration Reform and Immigrant Responsibility Act of 1996, 287 (g) agreements are partnerships formed between U.S. Immigration and Customs Enforcement (ICE) and state and local authorities that allow local law enforcement officers to perform federal immigration law enforcement. 
program in 2013, and stores and monitors travellers' entry and exit data (Department of Homeland Security 2016).

Along with internal and external border governance processes, there has also been a 'corporeal turn' with respect to bordering practices (Salter 2006; Amoore 2006; Provine and Doty 2011). Given the complexities of the border and the enforcement mechanisms practiced in the name of border security, this 'spatial stretching' really coincides with bordering practices that are associated with the personal body and to a great extent depend on the individual body in question. Accordingly, it is the individual who is perceived as a risk and/or a threat, which is why the state has increased its use of biometric technologies and biopolitical control (Muller 2011). Hyndman (2004a) refers to this phenomenon as the 'geopolitics of mobility', by which mechanisms are put in place in order to seek to control certain individual bodies at the expense of others; mobility, therefore, may be constrained and directly relates to 'corporeal access'. This distinction reveals the intersection between state bordering practices and the politics of mobility. Mobility becomes relational and politicized in that it is connected to the mobility and/or containment of others (Hyndman 2001) and the border becomes a relationship between the nation-state government and a particular body in question. The shift to bodies demonstrates how the border is enacted on bodies on the move. In other words, by seeking to cross a territorial border without the nation-state's permission, the individual body who is 'unauthorized' to cross is automatically categorized as an 'illegal' migrant. Through this category, the border accompanies migrants in their everyday lives and often forces people to put their bodies and lives at risk in order to survive (Holmes 2013). It is, as Khosravi (2011, p. 99) argues, an 'invisible border' where 'undesirable people ... are forced to be the border'. As borders become virtual and/or 'invisible', they are carried on bodies, are gendered, classed, and racialized, and are materialized in several ways, while also being used to govern and control migration (Amoore 2006; Squire 2011).

The bodies of migrant women add a level of complexity to this bordering dynamic. Nation-state border practices, by virtue of assigning legal categories to certain individual bodies, enforce the immobility of 'unauthorized' migrants. Critical feminist and feminist border theory illustrate that marginalized bodies are not only subordinated by categories such as 'unauthorized' or 'illegal'. Race, class, gender and nationality all equally affect (im)mobility (Hyndman 2001; Hyndman 2004a; Hyndman 2004b; Ruiz-Aho 2011; Cruz Salazar 2011; Pessar and Mahler 2003). Migrant women experience multiple barriers of marginalization or what Ruiz-Aho (2011) refers to as 'intersectional oppressions'. As Crenshaw (1991) noted in her analysis of intersectionality and African American women, feminist theorizing must examine gender oppression also within the context of other sources of oppression and subordination that women of colour experience. The idea of how the multiple oppressions of gender, race, class, and/or nationality all intersect to constitute a 'social body' is a core concept found in corporeal feminism (Grosz 1987; Grosz 1994; Bordo 1993; Bordo 1996). Feminist theories of the body challenge biological essentialism, which draws on a mind/body dichotomy that typically reaffirms the male/female binary by associating the mind with reason and rationality (i.e., the masculine) and the body with its (lesser) opposite of passion and emotion (i.e., the feminine) (Grosz 1987, p. 4). The body, however, is not fixed and not only a 'physical' or 'natural genetic' body, but rather also socially constructed (Bordo 1993, p. 142). Grosz (1987, p. 10) uses the metaphor of the body as an 'inscriptive/writing surface' to argue that the 'body's interiority is produced through its exterior inscription-its external environment'. Similar to the permanence of a 'social tattoo', the body is therefore 'marked, [and] constituted' by the 'inscriptions of cultural and personal values, norms, and commitments' (Grosz 1994, p. 142). A theory of the body should, therefore, account for both the biological body, as well as determining how the body can become socially constructed. Historical and socio-cultural factors make the 'lived body' or the body as experienced possible (Bordo 1993, p. 142). As Pratt illustrates (Pratt 2005, p. 1056), these historical, socio-cultural factors are gendered, racialized, and classed, and are used to create false binaries, which render women to the private sphere.

Both corporeal feminism and intersectionality can be applied when discussing the multiple vulnerabilities experienced by Central American women migrants because, while it is true that they 
experience the border produced by the nation-state on their bodies, most are also coming from poverty and a patriarchal society where structural gender violence is often the norm (ACNUR 2015). Furthermore, during their transit, they are placed in a more vulnerable position because they are women and, in this context, women are perceived as sexualized objects (Vogt 2016; Ruiz 2009), which in turn increases the likelihood of experiencing sexual and gender-based violence.

\subsection{The U.S.-Mexico Border, Enforcement Logics and Flaws}

This section examines border governance in the U.S. to show how border policies frame migrants as security 'threats', how they assist in sustaining restrictive border practices, and how similar practices extend to Mexico. Women migrants, who are framed as security threats, often fear detention and deportation and therefore attempt to remain hidden. Control and enforcement along the U.S.-Mexico border have undergone radical changes since the 1960s, where migrants entering from Mexico have become increasingly securitized. For instance, in his book Operation Gatekeeper, Nevins (2001) provides a useful historical trajectory of the securitization of 'unauthorized' migrants, which began to take hold in the 1960s. He notes that during the 1950s and early 1960s, border security and immigration were liberal in nature, failing to demand much political attention by governments and national security institutions alike. In the late 1960s, however, a shift occurred where the perception of crisis began to emerge among government officials and the public depicting the U.S.-Mexico border as dangerous and out of control. Mountz and Hiemstra (2014, p. 383), when discussing border crossings, illustrate that fear and insecurity are driving forces of securitization, where the discourse of 'crisis' is repeatedly used by nation-states, especially when 'migrants attempt to cross between regions of great economic disparity'. Indeed, there were several factors both contextual and agent-driven that engendered these perceptions of 'crisis' in the U.S.-Mexico border case. First, the success of the Chicano civil rights movement in the late 1960s, especially along the borderlands, led many to fear a possible U.S. Southwest secession. Second, in the 1970s, there was an economic downturn and energy shortage, which led to a fear of unemployment and the perception that immigrants would take U.S. jobs. Lastly, the conservative Nixon administration, which had declared a war on drugs and crime, often perpetuated a link between migrants and the drug trade, thus further criminalizing 'foreigners' (Nevins 2001, p. 78).

Similarly, Andreas $(2003,2009)$ and Duvell $(2011)$ have noted how the security framing of migrants as 'threats' continues to evolve, distinguishing between border security controls pre and post 11 September 2001 (9/11). In the 1990s, national security interests focused on the external physical border, creating and fortifying border fences. Unauthorized migration was primarily treated as a law enforcement matter on the U.S. side of the border and included an escalation of border policing (Andreas 2009). After 9/11, however, the expectation of success was significantly higher and, unrealistically, deterrence was required to be 100 percent (Andreas 2003). Subsequently, there was a prominent transformation in terms of border control and enforcement, which encouraged the blurring of the lines between the external and internal realms of the nation-state for the sake of national security. Border governance was to be implemented not only at border crossings but also internally, whether through work raids, local-federal immigration enforcement partnerships, and/or increased deportations (Nevins 2001; Doty 2010; Inda 2011; Coleman 2012). De Genova (2002) argues that the very real possibility of being deported places migrants in a constant state of 'deportability'. By instituting internal control within everyday life, the migrant is forced into a 'state of nonexistence', constantly fearing deportation. This form of productive power conditions migrants to live in a state of invisibility. The U.S. government continues to advance restrictive security mechanisms along the southern border to control mobility, which further contributes to the securitization of migrants and raises humanitarian concerns (Holmes 2013).

Overall, the concept of nation-state borders and all the diverse actors, institutions, technologies, and knowledges involved in their creation and maintenance reveals not only the popular anxieties about an increasingly borderless world with the onset of globalization, but also the contradictions involved with state sovereignty. Brown (2010) discusses the escalation of wall building in a world 
that is increasingly globalizing. She explains several paradoxes of a globalized world where there is the simultaneous opening (as with trade and goods) and blocking (as with the movement of people). A globalized world promotes universalization while at the same time pushing for exclusion and stratification. The most notable contradiction is the relationship between sovereignty and borders where it is the weakening of sovereignty that generates 'much of the frenzy of nation-state wall building today' but rather than being an expression of a sovereign nation-state, 'the new walls are icons of its [sovereignty's] erosion ... they [walls] reveal a tremulousness, vulnerability ... at the core of what they aim to express' (Brown 2010, p. 24). Thus, despite the astronomical costs and its limited effectiveness in terms of deterring migrants, borders continue to be legitimized by the political elite as an efficient form of governance because politicians fear losing their sovereignty or 'their symbolic control over the territorial boundaries', which justifies the nation-state as a 'body or a container for the polity' (Bigo 2002, p. 65).

\subsection{Beyond the Frontier: Border Logics Applied at the Mexico-Guatemala Border}

Similar border logics are being applied worldwide. Huysmans (2000) examines this 'fortress mentality' specifically in the European context where the European Union (EU) focuses on clamping down on the free movement of people at the expense of developing an appropriate response to the global issue of increased mobility of people. This fortress analogy has also been applied in the North American context and is made clear when observing the border enforcement logics applied at the Mexico-Guatemala border. In the summer of 2014, the Mexican government implemented the latest iteration of border enforcement policy aimed at the securitization of migrants. It came at a time when the Mexican government was receiving intense pressure from the U.S. administration with respect to border security, due to the media attention surrounding the humanitarian crisis of unaccompanied Central American children crossing into the Southern U.S. Indeed, a significant number of unaccompanied children from Central America arrived in the U.S., overwhelming Border Patrol (BP) personnel and causing a media frenzy and public outrage in many southern states (Meyer and Boggs 2014).

As a result of the humanitarian crisis at the U.S.-Mexico border, the Mexican government faced increased pressure from the Obama administration to combat the 'problem' of the arrival of irregular migrants. Rather than framing the issue as a humanitarian concern, using the narrative of asylum, the Mexican government tried to secure the border with Guatemala, and stop more migrants from travelling onward to the U.S. by increasing the detention and subsequent deportation of Central American migrants in Mexico. In July 2014, the Peña Nieto administration implemented PFS. Along with his Guatemalan counterpart, Otto Perez Molina, Peña Nieto agreed to implement this policy, of which the primary objective was to 'protect and safeguard the human rights of migrants entering and transiting through Mexico and to regulate international crossings so as to increase the development and security of the region' (Presidencia de la Republica 2014). This objective promotes two prominent, although seemingly contradictory, narratives: one associated with the protection and human rights of migrants and the other connected to the reinforcement of security by enhancing regulation and creating 'orderly' migratory movements.

Upon closer analysis, however, it appears that the PFS is more concerned with facilitating and enhancing restrictive forms of border controls as well as applying comparable border enforcement logics witnessed in the U.S. context. When the PFS was launched, it came with five distinct line action items. Four of the five action items relate to border security and controlling migratory movements, all of course in the name of the migrant's security and protection. The most notable claim to migrant protection is the use of a temporary visa scheme, the Tarjeta de Visitante Regional (regional visitor visa), which gives migrants a temporary regular status to move freely while on Mexican territory and thus be less prone to be victimized by organized criminal groups. This visa is a prime example of a policy that is gendered through a binary logic where migrants are framed as victims at risk, who need protection and control rather than as agents with rights. 
At first glance, this temporary visa appears to offer some protections to transit migrants. Nonetheless, in practical terms, it has several shortcomings with respect to migrant protection. First, this visa option is only applicable to Guatemalans and Belizeans, which leaves a large proportion of the migrant population outside the scope of eligibility. According to official statistics presented by the INM, out of the total Central American migrants it detained in $2014(119,714)$, only 47,794 were from Guatemala and 42 were from Belize. The remaining numbers represent migrants from El Salvador $(23,131)$ and Honduras $(47,521)$, and smaller numbers come from Costa Rica (31), Nicaragua (1180), and Panama (15) (Secretaría de Gobernación SEGOB). Of course, given the nature of official statistics, these figures do not include individuals who were able to evade authorities. However, by examining the statistics, we can conclude that the temporary visa declared by the PFS leaves a substantial portion of this transiting population without protection while in Mexico. As noted in more detail in the section below, women from El Salvador and Honduras experience escalating and targeted violence and fear of persecution, and are often the first to flee (United Nations High Commissioner for Refugees UNHCR), but they are not covered by this visa.

The temporality and the geographical applicability of the visa are equally flawed. For instance, of the small percentage of migrants that are able to acquire this visa, the protection afforded to them with this 'regular' migratory status is only three days long or a seventy-two-hour window. After this timeframe, migrants from Guatemala and Belize are once again 'irregular' if they do not return to their country of origin. Furthermore, the spatial mobility sanctioned with this visa is fairly restrictive as it only covers the southern states of Campeche, Quintana Roo, Chiapas, and Tabasco (Presidencia de la Republica 2014). Given these constraints, the primary objective of the policy does not appear to make sense. Protecting migrants while transiting through Mexico clearly implies, by definition, that they are, in fact, in transit to another location (in most cases to the U.S.). Why is access then restricted solely to the southernmost states, which is only one-third of the trajectory? Likewise, the journey to the U.S. is at least $2000 \mathrm{~km}$ long and thus a seventy-two-hour window equally places migrants in a precarious situation, as most are unable to reach the U.S. in three days, which is already a moot point as they are denied access to the northern states. Consequently, since the regional visitor visa is touted as a successful mechanism for the protection of migrants for the PFS, its primary objective instead should read as follows: 'to protect and safeguard the human rights of [some] migrants entering and transiting through [southern] Mexico [for a period of only three days]'.

Unfortunately, when looking at these contradictory and inconsistent policy mechanisms, the PFS does little to protect the rights of migrants who are transiting through Mexico. It does, however, promote and advance border security logics by enhancing nation-state control over this 'irregular' migrant population. By intensifying border security and increasing enforcement so as to bring 'order' to migration flows in Mexico, this program reinforces the securitization of migrants and benefits the nation-state by allowing it to have more access to knowledge and control of this population. It securitizes this population by viewing 'unauthorized' migration through a state security lens rather than through a humanitarian lens. Given the level of violence experienced in these Central American countries, particularly in Honduras, Guatemala, and El Salvador, where the homicide rates of each country are among the highest in the world (Declaración de Ginebra 2015), many migrants forced to flee their homes should be treated as seeking a place of refuge and protection from persecution (Human Rights Watch 2013; United Nations Office on Drugs and Crime UNODC).

Furthermore, by effectively promoting inter-institutional collaboration between different forms of authority including federal, state, and municipal security forces (a principal border security logic also practiced in the U.S.), the government criminalizes 'unauthorized' migrants, connecting them to policing and penal practices rather than asylum practices. Again, applying a binary logic, the migrants are either victims or criminals. One of the outcomes of the PFS, for example, was the creation of a Gendarmerie of 5000 Federal Police with military training in Tapachula, Chiapas (IACHR 2015). The increase in enforcement personnel in Mexico has resulted in a rise of internal border controls, especially the surge of checkpoints and raids. Rather than ensuring the safety of transit migrants, 
many migrant organizations have condemned the actions of the PFS, indicating that these enforcement operations are responsible for the increase of violence towards migrants by security agents and a rise of detentions and deportations without due process (Boggs 2015; Tourliere 2015; IACHR 2015). Finally, the program endorses the acquisition and access to data and more sophisticated data sharing among multiple government agencies. First, to obtain the regional visitor visa, the individual must be willing to register his/her biometric data with the Mexican government. In addition, there are guidelines set within the PFS for reinforcing intelligence networks in prominent transit zones in collaboration with other state authorities, increasing knowledge exchange between local, state, and federal counterparts and developing a technological platform for effective real-time biometric data sharing of migration registries (Presidencia de la Republica 2014). These border technologies again are seen in the U.S.

\section{Categories, Vulnerabilities, and Precarity}

Women migrants must confront this precarious migratory system in Mexico. Central American women migrants travelling through the country already face structural vulnerabilities ${ }^{3}$ even before they decide to venture north. Notable discrimination and unequal power hierarchies with respect to gender are prevalent in Central America and permeate most daily economic and social interactions. For example, due to prevalent socio-economic structures, women typically only have access to gendered occupations, which are predominantly deemed inferior when compared to men's labour (Raghuram 2004; Pratt 2004; Hondagneu-Sotelo 2001). This type of labour is usually found within the informal economy and includes domestic work or working in small-scale market stands (Hennebry et al. 2016). In addition, GBV in the NTCA is pervasive and impunity is the rule rather than the exception (United Nations High Commissioner for Refugees UNHCR; Human Rights Watch 2016; OHCHR 2016; Amnesty International 2016). Dr. Manjoo, the Special Rapporteur on Violence Against Women, during her visit to Honduras in 2014, noted not only that violence against women is systemic but also that incidents of violence are increasing. Using contested statistics from the Public Prosecutor's Office, she noted that in 2012, there were 'approximately 16,000 reported allegations of numerous manifestations of violence against women ... with $74.6 \%$ related to domestic and intra-family violence, and 20\% related to sexual offences (Manjoo 2014). El Salvador exhibits a similar situation, where high levels of domestic violence persist and 'Research shows that domestic violence and sexual abuse of women and girls in the private sphere remain largely invisible [because of] family and community pressure not to reveal domestic problems; economic dependency; fear of retaliatory violence by partners; poor awareness of rights among victims; lack of sufficient support services; and low confidence in the justice system' (Manjoo 2011, p. 7). For many women, it is precisely these structural vulnerabilities that become motivating factors for leaving their country of origin. Therefore, GBV is embedded in the migration process, as it is often a push factor for migration. Violence then continues during women's transit, and again may continue upon reaching their destination. Women leave to obtain better opportunities, not solely economic opportunities but also better social and educational opportunities, and a life free from violence.

Thus, being 'unauthorized' already places women migrants in a more vulnerable position vis-à-vis migrant men. It is equally important to note that migrant women may also be travelling with multiple oppressions that are socially constructed through power structures based on social differences, which in turn leads to multiple vulnerabilities. For example, they not only are women but may also be poor, and/or indigenous, and/or from Guatemala, El Salvador, Honduras. These multiple oppressions

3 I refer to structural vulnerabilities using Farmer's (2004) theoretical understanding of structural violence. Structural violence involves indirect forms of violence through historical social, economic, and political structures, in the form of gender inequality, racism, poverty, discrimination, and structural stereotypes, which together perpetuate and encourage everyday exclusion, exploitation, and marginalization. According to Farmer (2004, p. 307), structural violence "is violence exerted systematically, that is, indirectly, by everyone who belongs to a certain social order ... [and] informs the study of the social machinery of oppression". It is these structures that render a migrant's life precarious, a livelihood that is synonymous with insecurity, uncertainty, and unpredictability. 
differentiate based on gender, class, race, and nationality and are all constructed in a subordinate manner (Hyndman 2001). The state-imposed category of 'unauthorized' is added to this dynamic through border enforcement policies. Whether the category is 'unauthorized', 'illegal', 'alien', 'irregular', or 'undocumented', border security enforcement policies like the PFS, despite their claims of protection, force migrant women to put their bodies, health, and lives at risk in order to survive. As such, borders are ideological because 'they are productive and generative of placing people in new types of power relations with others' (Anderson et al. 2012, p. 76). Risk profiles, for example, classify and categorize between the legitimate and illegitimate or between the 'trusted traveler' and the 'illegal migrant'. The experiences of bordering can be quite different depending on which category is assigned, as some bodies are afforded more mobility than others. One is either deemed a 'safe -citizen' that needs to perform according to those bordering expectations (Salter 2004; Salter 2008), or an 'unauthorized' migrant that needs to run and hide to avoid apprehension and deportation.

An 'irregular' migratory category situates migrant women in a more marginalized and insecure position because, as soon as they cross into Mexico, they enter an illegal space, the Mexican nation-state which has prohibited their entry. They, in turn, occupy a clandestine or illicit presence (Coutin 2005) within the Mexican territory and must navigate their journey with this illegality in their everyday lives, thereby occupying a space of 'non-existence' (De Genova 2002). Women experience the border in their everyday world, because 'the borderline is not just at physical entry points at ports, airports, and land crossings', it is a process that has the potential to materialize anywhere (Nyers 2008, pp. 166-67). Therefore, the border follows and surrounds women migrants as they travel with 'illegality' or without state authority (Khosravi 2011). Living life as an 'unauthorized' migrant is connected to an emotional state of constant fear where women migrants are always afraid, afraid of being caught by migration agents, afraid of being deported, afraid of experiencing physical or sexual violence, and in the case of employment, afraid of being fired as well as deported, all due to a state-imposed border category.

\section{Transit Migration and Shadow Labour}

Being in transit represents a liminal state for women migrants due to the dynamic nature of migration. Defining transit migration is difficult because 'transit' may, and often does, change due to time and space. Temporally, for instance, migration is not a straightforward process of departure from the country of origin to arrival at the country of destination. Rather, it evolves in stages where expectations surrounding the journey prior to leaving home may differ significantly from the reality. This is especially the case for women categorized as 'irregular' or 'undocumented' as they face added challenges due to their migratory status. For instance, women may be robbed, raped, and/or kidnapped (Isacson et al. 2015; Diaz Prieto and Kuhner 2014; Comisión Nacional de los Derechos Humanos CNDH; Comisión Nacional de los Derechos Humanos CNDH). They may also simply run out of economic funds to continue their journey. These interruptions usually change the length of the overall journey as well as the spatial trajectory of the trip, and their plans must adjust to accommodate these new realities on the ground as well as moments of immobility (Brigden and Mainwaring 2016). Consequently, migrant women, who may not have initially set out to work during their transit, face challenges that may make them change course out of necessity and they must adapt themselves to succeed in the rest of their journey.

The climate of fear experienced due to the categorization discussed above is intertwined with this complex journey. It is directly connected to their everyday activities, including finding work while in-transit. Unlike temporary foreign workers, women migrants in transit do not have the documentation and/or the legal status to work while in Mexico. They are in a liminal position where they are simultaneously outside (in transition or not yet arrived), but also inside (travelling through) a national space (Chavez 1992). They may be physically present but also economically and socially absent and most are without the nation-state's protection (Coutin 2005). It is unsurprising, therefore, that these women acquire work illegally in the shadow market. Since they are afraid of being caught 
and deported while in transit, they engage in shadow labour ${ }^{4}$. This heightened fear leads to precarious conditions and various forms of exploitation.

With respect to labour, 'unauthorized' migrant women face discrimination in employment as their immigration status is directly connected to their employment status and the labour market to which they have access. The consequences of an 'irregular' status affect (1) their ability to secure employment and (2) labour market access and labour precarity. First, women migrants may find it difficult to find employment even within the informal labour market. According to a government representative I interviewed, Mexican nationals, for example, may discriminate against 'unauthorized' migrants because there is a stigma associated with foreigners, especially from Central America (Interview, 18 September 2014, Mexico). Typically, 'unauthorized' migrants are perceived in a negative light, especially given the pervasive national discourse, which frames migration as a security concern. I interviewed one migrant woman who describes her situation, which resulted in being refused work, as follows: 'People discriminated against me as soon as I mentioned I was from El Salvador. One lady said that the woman working for her before she stole from her so now she doesn't trust them [migrants]' (Interview, 27 October 2014, Mexico). If women are able to secure employment, it is governed and controlled by the employer in the home and, in most cases, 'employers have the right to dismiss a worker even if there is no "good" reason' (Hennebry et al. 2016, p. 52).

On the other hand, if women can procure employment within the informal sector, it is commonly in highly gendered job markets-either as a domestic worker, as a waitress, and/or as a bartender. Likewise, they suffer from labour precarity since these occupations deprive migrant women of a variety of legal protections. Employers know that they do not have work permits and often use their fears of deportation against them. Thus, women may be exploited by their employers either by working long hours, not being paid what was verbally agreed on, which can involve being paid less or simply not being paid at all, and/or being fired without just cause (Hennebry et al. 2016). A migration expert who works with a labour rights organization describes the situation where women may not have 'formal contracts, [and] their pay is arbitrary, so they don't have a stable income or job security; it's very easy to fire them' (Interview, 25 November 2014, Mexico).

In addition, women who work during their transit may face a lack of knowledge about the laws governing labour in Mexico and, if they do have the adequate knowledge, often fear accessing judicial mechanisms and coming forward to make a claim against the employer. The same may be said for access to health care. Most Central American migrant women who work during their transit are frequently employed in the informal domestic work sector, which is said to be 'one of the most vulnerable labour flows' (IMUMI and ONU Mujeres 2014). There are several factors that contribute to this vulnerability. First, many women may be live-in workers, which at first may seem advantageous because they would not incur living expenses. However, this type of live-in condition promotes more labour rights violations-especially being exploited by working longer than agreed upon while being paid the same. Moreover, these positions are traditionally paid very low wages, have no employment contract, and receive no vacation or vacation pay, no over-time pay, and/or sick leave (IMUMI and ONU Mujeres 2014, p. 15).

Lastly, there is the potential danger involved with occupations within the service sectors, such as working as a waitress or bartender. In the Mexican context, the lines between a waitress or bartender and a sex worker may become blurred, especially in the southern Mexico border zones, where bars in Chiapas are often also known for prostitution (Ruiz 2009). It is difficult to know the exact number of women who are working in the sex industry due to the negative stigma attached to this form of work and its hidden nature. Numbers are not accurately captured by official statistics and thus it is equally difficult to know which women enter the work voluntarily or are forced into it, which may also be a

4 Shadow labour represents economic activities and types of work that are not part of the formal economy and thus avoid government regulation and taxation. These forms of work may also be referred to as informal labour. 
blurry and contentious distinction. These that are forced into prostitution, again usually work in bars and/or brothels along the border in Chiapas (IMUMI and ONU Mujeres 2014, p. 15). This occupation places women in an extremely precarious position in that they are subject to physical and sexual abuse and exploitation. Nevertheless, since sex work is not considered a 'legal form' of work or a legitimate occupation, labour rights are unattainable, even in theory.

\section{Invisible Women Migrants}

Travelling without the nation-state's authority also implies that women transiting through Mexico need to become invisible to avoid detention and deportation. Since border security controls impose immobility and further contribute to marginalization, they make women insecure and vulnerable, forcing them to become invisible to survive while in transit. The state of invisibility poses several problems ${ }^{5}$. Being invisible during the journey, and not being able to freely access public spaces, exposes migrant women to increased danger and risk by virtue of not being seen. The consequences involved with being invisible may include severe exploitation, heightened violence, disappearance and even death. The transit routes that are accessed to avoid apprehension may prove more violent due to their secluded nature.

In Mexico, 'unauthorized' migrant women often remain hidden as their objective is to reach the U.S. and being detained and/or deported does not serve their goal. The consequences of this invisibility may be broken up into three issues: the mode of transportation used while in transit, the migration agents used to facilitate the journey, and the sex and gender-based human rights violations encountered while en route. First, the very nature of invisibility positions women migrants outside conventional means of travel. Women choose the mode of transportation, which will afford them the greatest invisibility. Traditionally, migrants, especially those that did not have sufficient economic resources for alternate transportation, have boarded the freight train known as 'La Bestia' [the Beast]. The freight train 'La Bestia' is a commercial cargo train with multiple northbound routes. It stretches from the Mexico-Guatemala border all the way to the U.S.-Mexico border. This mode of transportation is used in order to access a hidden transit route. The irony, of course, is that as more migrants continued to use this transportation route, it also became more known as an established transit corridor (Coutin 2005). Both criminal organizations and nation-state authorities became familiar with these routes and transit migration became an economic market to be exploited. Criminals, for instance, prey on the migrants that board the train. Criminal gangs often board the trains and demand that migrants give them US\$100-200 to continue their journey. If they do not comply, they are often beaten, thrown off the train and left for dead (Isacson et al. 2015; Interview, 7 October 2014, Mexico).

According to the Mexican government, one of the primary reasons for implementing the PFS was to stop these human rights abuses along the train route. Once the PFS was realized, however, there was an enormous increase in the number of raids occurring along the train routes by INM officials and other state authorities. The result has not been positive for women migrants. The intensity of raids along the prominent train routes means that migrants now have to find alternate and more secluded routes, often in deeply wooded rural areas of the interior, far from any type of protection, and often travel on foot for days. Migrants are even less visible and more vulnerable than they were prior to the PFS (Boggs 2015). Transit migrants continue to experience severe abuses that are perpetrated by both state and non-state actors. By being pushed into ever more secluded areas, migrants become easier prey for criminal groups who capitalize on this invisibility, target migrants who venture into rural areas, and either rob, kidnap, or extort them. Since 2014, not only has there been a surge in the amount of robberies experienced by migrants (Boggs 2015; Meyer and Boggs 2014),

5 While the purpose of this article is to illustrate how invisibility poses problems for 'unauthorized' migrant women in transit, I recognize that there are instances where invisibility may be advantageous for women, such as dressing like a man, in order to avoid sexual attention. 
but there has been public outcry from human rights organizations like Amnesty International (AI) which claim that Mexico has become a 'mortal trap for migrants' and urges the 'Mexican authorities to investigate the atrocious increase of violent attacks against undocumented migrants by criminal groups' (Amnesty Internatioal 2015; BBC 2015). According to an AI press release, more than 200 migrants were targets of a brutal attack, and several were killed by armed groups in two separate attacks [in a span of two months] (Amnesty Internatioal 2015; Avila Perez 2015).

Women migrants also become victims to abuses by Mexican state actors. In 2009 and 2011, the Comisión Nacional de Derechos Humanos (CNDH) [National Commission of Human Rights] in Mexico published reports indicating that federal, state, and municipal authorities were responsible for human rights violations including robbery, kidnapping, and extortion. Similarly, in 2013, a prominent Mexican NGO, Red de Documentación de las Organizaciones Defensoras de Migrantes documented in their report testimony by migrants in transit who had been assaulted by Mexican authorities (Red de Documentacion de las Organizaciones Defensoras de Migrantes RDODM). While I interviewed a woman migrant, she expressed that she was assaulted by municipal police forces in Tuxtla, Chiapas while trying to transit north. She stressed that she was taken in their patrol car to a wooded area where she was physically assaulted, robbed of all her money and her documentation (Interview, 29 October 2014, Mexico). After the implementation of the PFS, there have been numerous reports from NGOs and migrant shelters that abuses by authorities continue unabated during these raids and enforcement operations, where soldiers not only increasingly take part in operations, but frequently use violence to detain migrants (Amnesty Internatioal 2015; La Prensa 2015; IACHR 2015). International organizations have equally expressed their concerns over the human rights violations occurring in Mexico. The Inter-American Commission on Human Rights, in a press release, explicitly urged the Mexican government to 'implement international standards regarding the use of force in immigration control operations; investigate, on its own initiative, acts such as those described above; punish agents responsible for human rights violations; and provide reparation to the victims of these violations' (IACHR 2015).

\subsection{Coyotes: the Good and the Ugly}

Forced invisibility means that migrants need not only to use such forms of transportation as La Bestia but also to travel with the help of migration agents, who facilitate the process of migration. Specifically, migrants begin to hide their presence even prior to departing from their country of origin by hiring a 'coyote' or a 'pollero' who assists them in navigating their migratory journey. Coyotes/polleros are migration facilitators who charge a fee to help smuggle migrants through Mexico and into the U.S. As soon as the decision is made to hire a smuggler, migrants enter into this clandestine space, as these migration agents do not operate in public spaces. Their 'unauthorized' status and the arduous, hidden journey through Mexico make it almost impossible to survive and arrive in the U.S. without the assistance of coyotes/polleros.

Hiring a coyote/pollero may have several advantages and disadvantages for women migrants. One advantage is that many women migrants attempting to transit are unfamiliar with the territory and unaware of the best transit routes to reach their destination. This is especially the case since the implementation of the PFS in 2014, which has pushed migrants into more remote spaces. Since for many women migration to the U.S. is a survival strategy, most would be unable to move without the aid of a smuggler. Coyotes are knowledgeable and provide a service for these women; it is their business. One of the main problems with this business for women migrants, however, is how this type of work has evolved into one that is connected with organized criminal groups. This reality increases the insecurity and potential for human rights abuses for women migrants who essentially are taking a gamble and hoping they can trust these migration agents in their journeys.

Unfortunately for migrants, the business of coyotes/polleros has undergone a change in Mexico over the last ten to fifteen years (Interview, 30 September 2014, Mexico). Traditionally, these migration facilitators were from the same community and were therefore known and trusted among those 
individuals who resided in these neighbourhoods. People knew that the coyote had completed the journey north in the past and had helped many migrants on their road to the U.S. Currently, however, many traditional coyotes have been co-opted (by either threat or force) into a more sophisticated system of coyotes, which has direct links to criminal groups (Interview, 30 September 2014, Mexico). They operate as a sophisticated network with several coyotes involved in the transit journey. As a result, migrants will meet and encounter many individual coyotes throughout their trajectory. Each coyote will be responsible for a specific region and can navigate it well. Since the group of migrants are passed off from one coyote to another, there is a lack of established trust in this relationship. It is strictly a monetary transaction. In addition, it is important to note that escalating border controls have increased not only the need for coyotes but also the price of acquiring their services. As the pathways through Mexico become more dangerous and violent, the services of coyotes become more expensive to account for the risks involved. The average price for these services now ranges from US\$5000 to US\$10,000 (Interview, 7 October 2014, Mexico). Consequently, it has become an increasingly common practice for migrants to take out loans to pay these fees (Coutin 2005).

The lack of trust experienced by women migrants with regards to the coyote relationship may translate into abuses involving abandonment, kidnapping, and extortion. First, due to their 'intersectional oppressions', women may be perceived by their coyotes as physically weaker compared to men and thus more disposable when compared to the rest of the migrant group. Some women may be at a physical disadvantage, for example, when having to outrun state authorities. Coyotes make it very clear at the beginning of the arrangement that if anyone is unable to keep up with the rest of the group, they risk being left behind. Women travelling with children may be especially insecure since they are more likely unable to keep up with the rest of the group (Women's Refugee Commission 2013). Second, many women migrants face kidnapping combined with extortion. Coyotes may try to take advantage of these women by extorting more money from their families than originally agreed upon during the business arrangement. In this scenario, women are kidnapped and taken to 'safe houses' where they are kept until a ransom of money is paid for their release (Meyer 2010; Interview, 11 October 2014, Mexico).

\subsection{Sexual Violence}

Perhaps the most salient danger which women migrants are exposed to during their journey through Mexico is sexual violence. Due to their sex, these individuals are victimized in gender-specific ways. Furthermore, given their state-imposed invisibility, if physically assaulted or raped, migrant women feel unable to seek social justice even though their human rights have been gravely violated. Sexual violence is increasingly common along transit routes and the main culprits are not only criminal gang members or coyotes, but also migrant men, migration officers, police officers and/or security agents on the freight train. Sadly, this reality is so common that being sexually assaulted has become the norm when discussing migrant women in Mexico and was pointed out by several interviewees (Interviews with NGO representatives, migrant shelter administrators, and migrants in-transit). This 'new normal' becomes an important mental and physical preparation for women migrants prior to departure in that many women take some form of contraception prior to starting their journey (Interview, 29 October 2014, Mexico).

Equally disturbing are two links that have been associated with the increase in sexual violence. One is the connection to forced disappearances and human trafficking. Women en-route are disappearing and being forced into prostitution, especially in Tapachula, Chiapas-the southern border zones. They work in bars where traffickers can exploit their economic vulnerabilities promising more lucrative employment (Interview, 13 November 2014, Mexico; Diaz Prieto and Kuhner 2014; Rodriguez and Davies 2012). Moreover, a 'significant number of them [women] are minors and they often suffer from extortion by various authorities' (ONU Mujeres 2015, p. 15). The Convention on the Elimination of Discrimination against Women (CEDAW) highlighted this problem as a principal area of concern in Mexico and called for a harmonization of criminalization initiatives between 
federal- and state-level mechanisms as well as measures being put in place for prevention and prosecution (The United Nations 1988). The other connection relates to sexual violence and kidnapping. Kidnapping and extortion have been identified as consequences of invisibility. Nonetheless, women migrants who are kidnapped are also often subjected to sexual abuse by their captor(s). According to the (Comisión Nacional de los Derechos Humanos CNDH, p. 6), the 'sexual abuse and the frequent cases of rape are persistently associated with events of kidnapping of women migrants'. Overall, for women, being categorized as 'unauthorized' migrants starts a cycle. First, the category places women in a clandestine space, where the fear of detention and deportation forces them to try to remain hidden while travelling through Mexico. Second, remaining invisible often translates into women having to access remote areas, which become primary targets of criminal groups. In these secluded areas, women cannot only be exposed to sexual violence, but kidnapping and subsequently trafficking (Martínez 2014). Lastly, if they do survive, they may again fear coming forward as this can result in their detention and deportation.

\section{Conclusions}

In summary, Mexico presents a critical case for examining border controls and transit migration, especially with regards to women migrants. The close geographical proximity to the U.S. border increases the pressure for the Mexican government to secure its borders, whether external or internal. Adopting similar border logics to that of the U.S., however, has allowed the Mexican nation-state to produce and control the 'unauthorized' or 'irregular' migrant population in the name of human rights and 'orderly' migratory movements. This type of 'protection from harm' national discourse (Anderson 2012) attempts to change the optics internationally where the Mexican government appears to be implementing these policies to protect migrants. Using this narrative, in turn, characterizes the nation-state as a 'protector', absolving it from criticism, whereas, in reality, it is implicated in creating this vulnerability and violating human rights by (re)producing 'irregular' migrants.

By incorporating a corporeal feminist perspective and including a focus on the embodied border, I show how once migrant women cross the Guatemala-Mexico boundary, the border follows them, internally, as they travel throughout Mexico. On the ground, not only have the border enforcement controls, implemented by the PFS, caused greater violence and insecurity for women migrants with respect to their transit, but these controls also support their further marginalization, vulnerability, and precarity in a gendered informal labour market. For women migrants, the category of being 'unauthorized' forces them to remain hidden or else to face detention and subsequent deportation, and also exposes them to greater danger and risk. Furthermore, by addressing intersectional oppressions, my article advances the understanding of migrant women by appreciating that a body is constituted by lived experiences based on historical, socio-political, and economic factors. This kind of analysis, in turn, shapes our understanding so we do not neglect the gendered, racialized, and classed boundaries that intersect with the nation-state's border and which, taken together, constitute the subordinate migrant-subject. This article has argued that despite claiming to protect women migrants from human rights violations, these border controls construct and promote pejorative categories as well as forced invisibility, which enhance risk and danger for the migrant women who are transiting through Mexico and trying to reach the U.S. for better life opportunities.

Funding: This research was funded by Borders in Globalization, a partnership grant funded by the Social Sciences and Humanities Research Council of Canada (SSHRC) (Grant no.: 895-2012-1022). The APC was also funded by Borders in Globalization.

Conflicts of Interest: The author declares no conflict of interest. The funders had no role in the design of the study; in the collection, analyses, or interpretation of data; in the writing of the manuscript, or in the decision to publish the results. 


\section{References}

Abrahamsen, Rita, and Michael Williams. 2009. Security Beyond the State: Global Security Assemblages in International Politics. International Political Sociology 3: 1-17. [CrossRef]

ACNUR. 2015. Mujeres en Fuga: Historias de Mujeres Refugiadas de El Salvador, Guatemala, Honduras y México. México D.F.: ACNUR.

Amnesty Internatioal. 2015. Comunicado: Mexico debe Investigar el Atroz Aumento de los Ataques y Homicidios de Migrantes. Amnesty International. June 18. Available online: http://amnistia.org.mx/nuevo/2015/06/18/ mexico-debe-investigar-el-atroz-aumento-de-los-ataques-y-homicidios-de-migrantes/?o=n (accessed on 19 April 2017).

Amnesty International. 2016. Home Sweet Home? Honduras, Guatemala and El Salvador's Role in a Deepening Refugee Crisis. London: Amnesty International.

Amoore, Louise. 2006. Biometric Borders: Governing Mobilities in the War on Terror. Political Geography 25: 336-51. [CrossRef]

Amoore, Louise. 2011. On the Line: Writing Geography of the Virtual Border. Political Geography 30: 61-69.

Anderson, Bridget. 2012. Where's the Harm in That? Immigration Enforcement, Trafficking, and the Protection of Migrants' Rights. American Behavioral Scientist 56: 1241-57. [CrossRef]

Anderson, Bridget, Nandita Sharma, and Cynthia Wright. 2012. 'We Are All Foreigners' No Borders as a Practical Political Project. In Citizenship, Migrant Activism and the Politics of Movement. New York: Routledge, pp. 73-91.

Andreas, Peter. 2003. A Tale of Two Borders. San Diego: CCIS.

Andreas, Peter. 2009. Border Games: Policing the U.S.-Mexico Divide, 2nd ed. Cornell Studies in Political Economy. Ithaca: Cornell University Press.

Avila Perez, Edgar. 2015. Niegan que haya grupo migrantes desaparecidos en Veracruz. El Universal. June 18. Available online: http://www.eluniversal.com.mx/estados/2015/veracruz-migrantes-desaparecidos-1108440. html?utm_medium=twitter\&utm_source=twitterfeed (accessed on 10 April 2017).

Balibar, Etienne. 2002. World Borders, Political Borders. PMLA 117: 71-78. [CrossRef]

BBC. 2015. Aministia Internacional insta a Mexico Investigar Ataques contra Migrantes. BBC Mundo. June 18. Available online: http://www.bbc.com/mundo/noticias/2015/06/150617_mexico_ataques_migrantes_ investigacion_amnistia_internacional_jp (accessed on 20 April 2017).

Bigo, Didier. 2002. Security and Immigration: Toward a Critique of the Governmentality of Unease. Alternatives: Global, Local, Political 27: 63-92. [CrossRef]

Boggs, Clay. 2015. Mexico's Southern Border Plan: More Deportations and Widespread Human Rights Violations. Washington Office on Latin America (WOLA). March 19. Available online: http://www.wola.org/commentary/update_on_mexico_s_southern_border_plan_new_routes_more_ deportations_and_widespread_human (accessed on 20 April 2017).

Bordo, Susan. 1993. Unbearable Weight: Feminism, Western Culture, and the Body. Berkeley: University of California Press.

Bordo, Susan. 1996. The Feminist as Other. Metaphilosophy 27: 10-27. [CrossRef]

Brigden, Noelle, and Ċetta Mainwaring. 2016. Matryoshka Journeys: Im/Mobility During Migration. Geopolitics 21: 407-34. [CrossRef]

Brown, Wendy. 2010. Walled States, Waning Sovereignty. Brooklyn: Zone Books.

Chavez, Leo Ralph. 1992. Shadowed Lives: Undocumented Immigrants in American Society. Case Studies in Cultural Anthropology. Fort Worth: Harcourt Brace College Publishers.

Comisión Nacional de los Derechos Humanos (CNDH). 2009. Informe Especial sobre los Casos de Secuestro en Contra de Migrantes. Mexico, D.F.: CNDH.

Comisión Nacional de los Derechos Humanos (CNDH). 2011. Informe Especial sobre Secuestro de Migrantes en Mexico. Mexico, D.F.: CNDH.

Coleman, Mathew. 2012. The 'Local' Migration State: The Site-Specific Devolution of Immigration Enforcement in the U.S. South. Law and Policy 34: 159-90. [CrossRef]

Coutin, Susan Bibler. 2005. Being En Route. American Anthropologist 107: 195-206. [CrossRef]

Crenshaw, Kimberle. 1991. Mapping the Margins: Intersectionality, Identity Politics, and Violence against Women of Color. Stanford Law Review 43: 1241-55. [CrossRef] 
Cruz Salazar, Tania. 2011. Racismo Cultural Y Representaciones de Inmigrantes Centroamericanos En Chiapas. Migraciones Internacionales 6: 133-57.

De Genova, Nicholas. 2002. Migrant 'Illegality' and Deportability in Everyday Life. Annual Review of Anthropology 31: 419-47. [CrossRef]

De Genova, Nicholas. 2004. The Legal Productionn of Mexican/Migrant 'Illegality'. Latino Studies 2: 160-85. [CrossRef]

Declaración de Ginebra. 2015. Global Burden of Armed Violence 2015. Geneva: Geneva Declaration Secretariat.

Department of Homeland Security. 2016. Office of Biometric Identity Management Identification Services. Available online: https://www.dhs.gov/obim-biometric-identification-services (accessed on 10 April 2017).

Diaz Prieto, Gabriela, and Gretchen Kuhner. 2014. Un Viaje Sin Rastros. Mexico D.F.: Instituto para las Mujeres en la Migracion (IMUMI).

Doty, Roxanne. 2010. The Anti-Immigrant Movement and the Politics of Exceptionalism. Washington, D.C.: Immigration Policy Center.

Duvell, Franck. 2011. Irregular Migration. In Global Migration Governance. London: Oxford University Press, pp. 78-108.

Farmer, Paul. 2004. An Anthropology of Structural Violence. Current Anthropology 45: 305-25. [CrossRef]

Grosz, Elizabeth. 1987. Notes towards a Corporal Feminism. AFS 5: 1-15.

Grosz, Elizabeth. 1994. Volatile Bodies: Toward a Corporeal Feminism. Theories of Representation and Difference. Bloomington: Indiana University Press.

Hennebry, Jenna, Keegan Williams, and Margaret Walton-Roberts. 2016. Women Working Worldwide: A Situational Analysis of Women Migrant Workers. New York: UN Women.

Holmes, S.M. 2013. 'Is It Worth Risking Your Life?': Ethnography, Risk and Death on the U.S.-Mexico Border. Social Science and Medicine, 1-9. [CrossRef]

Hondagneu-Sotelo, Pierrette. 2001. Doméstica: Immigrant Workers Cleaning and Caring in the Shadows of Affluence. Berkeley: University of California Press.

Human Rights Watch. 2013. World Report 2013: Guatemala. New York: Human Rights Watch.

Human Rights Watch. 2016. World Report 2016: Guatemala. New York: Human Rights Watch.

Huysmans, Jef. 2000. The European Union and the securitization of migration. Journal of Common Market Studies 38: 751-77. [CrossRef]

Huysmans, Jef. 2006. The Politics of Insecurity. Fear, Migration and Asylum in the EU. London: New York: Routledge. Hyndman, Jennifer. 2001. Towards a Feminist Geopolitics. Canadian Geographer/Le Géographe Canadien 45: 210-22. [CrossRef]

Hyndman, Jennifer. 2004a. The Geopolitics of Mobility. In Mapping Women, Making Politics: Feminist Perspectives on Political Geography. New York: Routledge, pp. 169-84.

Hyndman, Jennifer. 2004b. Mind the Gap: Bridging Feminist and Political Geography through Geopolitics. Political Geography 23: 307-22. [CrossRef]

IACHR. 2015. Press Release: AICHR Expresses Concern over Mexico's Southern Border Plan. OAS—IACHR. June 10. Available online: http://www.oas.org/en/iachr/media_center/PReleases/2015/065.asp (accessed on 21 April 2017).

IMUMI and ONU Mujeres. 2014. Las Trabajadoras Migrantes Centroamericanas en Chiapas: Recomendaciones de Politica Pública Para Garantizar el Ejercicio de sus Derechos. Mexico D.F.: ONU Mujeres.

Inda, Jonathan Xavier. 2011. Borderzones of Enforcement: Criminalization, Workplace Raids, and Migrant Counterconducts. In The Contested Politics of Mobility: Borderzones and Irregularity. Edited by Vicki Squire. London: Routledge.

Isacson, Adam, Maureen Meyer, and Gabriela Morales. 2015. Mexico's Other Border: Security, Migration, and the Humanitarian Crisis at the Line with Central America. Washington: Washington Office on Latin America (WOLA).

Johnson, Corey, Reece Jones, Anssi Paasi, Louise Amoore, Alison Mountz, Mark Salter, and Chris Rumford. 2011. Interventions on Rethinking 'the Border' in Border Studies. Political Geography 30: 61-69. [CrossRef]

Kaldor, Mary. 2007. New \& Old Wars. Stanford: Stanford University Press.

Khosravi, Shahram. 2011. "Illegal" Traveller: An Auto-Ethnography of Borders. Basingstoke: Palgrave Macmillan. 
La Prensa. 2015. Migrantes Hondurenos, victimas de la caceria Mexicana. La Prensa. June 22. Available online: http://www.laprensa.hn/mundo/851872-410/migrantes-hondure\%C3\%B1os-v\%C3\%ADctimas-dela-cacer\%C3\%ADa-mexicana (accessed on 10 April 2017).

Lahav, Gallya, and Virgine Guiraudon. 2000. Comparative Perspective on Border Control: Away From the Border and Outside the State. In The Wall around the West: State Borders and Immigration Controls in North America and Europe. Edited by Peter Andreas and Timothy Snyder. Oxford: Rowman and Littlefield Publishers.

Manjoo, Rashida. 2011. Report of the Special Rapporteur on Violence against Women, Its Causes and Consequences, on Her Follow-up Mission to El Salvador (17-19 March 2010). New York: UNGA-Human Rights Council.

Manjoo, Rashida. 2014. Special Rapporteur on Violence against Women Finalizes Country Mission to Honduras and Calls for Urgent Action to Address the Culture of Impunity for Crimes against Women and Girls. New York: UNGA-Human Rights Council.

Martínez, Oscar. 2014. The Beast: Riding the Rails and Dodging Narcos on the Migrant Trail. London: Verso.

Meyer, Maureen. 2010. A Dangerous Journey through Mexico: Human Rights Violations against Migrants in Transit. Washington: The Washington Office on Latin America (WOLA).

Meyer, Maureen, and Clay Boggs. 2014. New Developments along Mexico's Southern Border. Washington Office on Latin America (WOLA). October 1. Available online: http://www.wola.org/commentary/new_developments_ along_mexico_s_southern_border (accessed on 21 April 2017).

Mountz, Alison. 2011. Specters at the Port of Entry: Understanding State Mobilities through an Ontology of Exclusion. Mobilities 6: 317-34. [CrossRef]

Mountz, Alison. 2015. In/Visibility and the Securitization of Migration: Shaping Publics through Border Enforcement on Islands. Cultural Politics 11: 184-200. [CrossRef]

Mountz, Alison, and Nancy Hiemstra. 2014. Chaos and Crisis: Dissecting the Spatiotemporal Logics of Contemporary Migrations and State Practices. Annals of the Association of American Geographers 104: 382-90. [CrossRef]

Muller, Benjamin. 2011. Security, Risk and the Biometric State: Governing Borders and Bodies. PRIO New Security Studies. London: Routledge.

Nevins, Joseph. 2001. Operation Gatekeeper and beyond: The War On "illegals" and the Remaking of the U.S.-Mexico Boundary, 2nd ed. New York: Routledge.

Nyers, Peter. 2008. No One Is Illegal Between City and Nation. In Acts of Citizenship. Distributed in the USA by Palgrave Macmillan. London and New York: Zed Books Ltd., pp. 160-81.

OHCHR. 2016. Situation of Migrants in Transit. Geneva: Office of the United Nations High Commissioner for Human Rights.

ONU Mujeres. 2015. Las Trabajadoras Migrantes en la Frontera Sur de Mexico. Mexico D.F.: ONU Mujeres.

Parker, Noel, and Nick Vaughan-Williams. 2009. Lines in the Sand? Towards an Agenda for Critical Border Studies. Geopolitics 14: 582-87. [CrossRef]

Parker, Noel, and Nick Vaughan-Williams. 2012. Critical Border Studies: Broadening and Deepening the 'Lines in the Sand' Agenda. Geopolitics 17: 727-33. [CrossRef]

Pessar, Patricia, and Sarah Mahler. 2003. Transnational Migration: Bringing Gender In. International Migration Review 37: 812-46. [CrossRef]

Pratt, Geraldine. 2004. Working Feminism. Philadelphia: Temple University Press.

Pratt, Geraldine. 2005. Abandoned Women and Spaces of the Exception. Antipode 37: 1052-78. [CrossRef]

Presidencia de la Republica. 2014. Pone en Marcha el Presidente Enrique Pena Nieto el Programa Frontera Sur. Available online: http://www.presidencia.gob.mx/articulos-prensa/pone-en-marcha-el-presidente-enriquepena-nieto-el-programa-frontera-sur/ (accessed on 20 April 2017).

Provine, Doris Marie, and Roxanne Lynn Doty. 2011. The criminalization of immigrants as a racial project. Journal of Contemporary Criminal Justice 27: 261-77. [CrossRef]

Raghuram, Parvati. 2004. Crossing Borders: Gender and Migration. In Mapping Women, Making Politics: Feminist Perspectives on Political Geography. New York: Routledge, pp. 185-97.

Red de Documentacion de las Organizaciones Defensoras de Migrantes (RDODM). 2013. Narrativas de la Trasmigracion Centroamericana en su paso por Mexico_Resumen Ejecutivo. Mexico D.F.: Servicio Jesuita a Migrantes.

Rodriguez, Luna, and Maisie Davies. 2012. Trafficking of Women in Central America and Mexico. London: Central American Women's Network (CAWN). 
Ruiz, Olivia. 2009. Women, Migration, and Sexual Violence: Lessons from Mexico's Borders. In Human Rights along the U.S.-Mexico Border: Gendered Violence and Insecurity. Edited by Kathleen Staudt and Tony Payan. Tucson: University of Arizona Press, pp. 31-47.

Ruiz-Aho, Elena. 2011. Feminist Border Thought. In Routledge International Handbook of Contemporary Social and Political Theory. New York: Routledge.

Rumford, Chris. 2006. Theorizing Borders. European Journal of Social Theory 9: 155-69. [CrossRef]

Rumford, Chris. 2011. Seeing like a Border. Political Geography 30: 61-69.

Salter, Mark B. 2004. Passports, Mobility, and Security: How Smart Can the Border Be? International Studies Perspectives 5: 71-91. [CrossRef]

Salter, Mark B. 2006. The global visa regime and the political technologies of the international self: borders, bodies, biopolitics. Alternatives: Global, Local, Political 31: 167-189. [CrossRef]

Salter, Mark B., ed. 2008. Politics at the Airport. Minneapolis: University of Minnesota Press.

Secretaría de Gobernación (SEGOB)-INM. 2014. Boletín Mensual de Estadísticas Migratorias. Mexico D.F.: Mexico. Secretaría de Gobernación (SEGOB)-INM. 2015. Boletin Estadistico 2015. Mexico, D.F.: Secretaria de Gobernacion. Sprague, Joey. 2016. Feminist Methodologies for Critical Researchers: Bridging Differences. Lanham: Rowman \& Littlefield.

Squire, Vicki, ed. 2011. The Contested Politics of Mobility: Borderzones and Irregularity. Routledge Advances in International Relations and Global Politics. London and New York: Routledge, vol. 87.

The United Nations. 1988. Convention on the Elimination of All Forms of Discrimination against Women.

Tourliere, Mathieu. 2015. Mexico Deporta Cada Dia a 424 Centroamericanos. Proceso. April 6. Available online: http://www.proceso.com.mx/?p=400428 (accessed on 10 April 2017).

United Nations High Commissioner for Refugees (UNHCR). 2015. Women on the Run: First-Hand Accounts of Refugees Fleeing El Salvador, Guatemala, Honduras and Mexico. Washington: UNHCR.

United Nations Office on Drugs and Crime (UNODC). 2013. UNODC Homicide Statistics: Intentional Homicide, Count and Rate per 100,000 Population (1995-2011). UNODC: Available online: https://www.unodc.org/unodc/ en/data-and-analysis/homicide.html (accessed on 10 April 2017).

Vogt, Wendy A. 2016. Stuck in the Middle with You: The Intimate Labours of Mobility and Smuggling along Mexico's Migrant Route. Geopolitics 21: 366-86. [CrossRef]

Walters, William. 2006. Border/Control. European Journal of Social Theory 9: 187-203. [CrossRef]

Weiner, Myron. 1993. Security, Stability, and International Migration. International Security 17: 91-126. [CrossRef] Women's Refugee Commission. 2013. Women Migrants Who Brave the Border. New York: Women's Refugee Commission.

Washington Office on Latin America (WOLA). 2015. Border Statistics Update: Mexico's Increased Enforcement Matches U.S. Border Efforts. Washington, D.C.: Washington Office on Latin America, Available online: https://www.wola.org/2015/05/border-statistics-update-mexicos-increased-enforcement-matchesus-border-efforts/ (accessed on 21 April 2017).

Zolberg, A. R. 1999. Matters of State: Theorizing Immigration Policy. In The Handbook of International Migration: The American Experience. New York: Russell Sage, pp. 71-93.

(C) 2019 by the author. Licensee MDPI, Basel, Switzerland. This article is an open access article distributed under the terms and conditions of the Creative Commons Attribution (CC BY) license (http://creativecommons.org/licenses/by/4.0/). 